\title{
Student Housing: Trends, Preferences And Needs
}

Claire Reeves La Roche, Longwood University, USA

Mary A. Flanigan, Longwood University, USA

P. Kenneth Copeland, Jr., Longwood University, USA

\begin{abstract}
To attract and retain students, universities are confronted with increased demand to provide housing options that meet the new expectations of the millennial generation. Recent trends and housing preferences are examined. The results of surveys detailing some of these new demands and how universities are attempting to address these demands are discussed. Additionally, universities are under pressure to efficiently use their limited resources and, as government support for higher education declines, public universities are seeking other sources of funding for major projects. Suggestions are made for unique partnering and financing options.
\end{abstract}

Keywords: Student housing, dormitory, housing preferences

\section{INTRODUCTION}

थ nlike their "baby-boomer" parents who were used to sharing a bedroom and bathroom, the students of the millennial generation have higher expectations for their student housing. The traditional dormitory with hall bathrooms and gang showers are quickly becoming a thing of the past. Private firms are competing with on-campus housing and tapping into the lucrative student housing market. Many privately-owned student housing developers are offering attractive, secure housing options that provide opportunities for students to socialize.

With the average high school senior applying to twenty or more colleges (CollegeBoard), housing is a tangible marketing tool as well as a way for a university to differentiate itself. The Center for Facilities Research of the APPA conducted a study of nearly 14,000 students. The purpose of the study was to determine "the relative importance of an institution's physical assets on a student's choice of higher education institutions" and "the relative importance of various facilities in the decision process...." (Cain) The study found that "two-thirds of the respondents indicated the Overall Quality of the Campus Facilities and that half of the respondents indicated the Attractiveness of the Campus were "Essential "or "Very Important" to their decision." (Cain) To determine which facilities were most important to see on a campus visit, respondents were asked to rank facilities. "Residence Halls on Campus" were ranked second with 53.1 percent feeling they were important to see on a campus visit. Ranked first were facilities related to the major course of study. Respondents were asked to pick the one facility that "had the greatest impact on their decision" in selecting a college. Ranked third, with $11.5 \%$, was residential space. Poorly maintained or inadequate facilities were listed as the number one reason for rejecting an institution. (Cain)

The current economic crisis is being felt by both state supported and private colleges and universities. While tuition and fees are increasing faster than inflation (4.9\% greater than inflation from 1999-2000 to 2009-2010 for four- year public institutions) many states are limiting the amount of increased costs that may be recouped through tuition increases. (CollegeBoard) To meet the financial challenges as well as student expectations, institutions are looking for alternatives for financing housing projects. (CollegeBoard) A more immediate problem facing institutions is the expected increase in college enrollments and the ability of schools to meet that demand.

This paper describes the national trends in student housing and the results of surveys of student preferences both nationally and at one university. The paper concludes with a discussion of the problems and 
opportunities for financing student residential developments.

\section{HOUSING PREFERENCES OF THE MILLENNIAL STUDENT}

University Business identified six trends in campus housing: Luxury, Privacy, Privatization, Live and Learn, Safety and Security, and Go Green. (Angelo) While these trends address all aspects of student housing, "The needs and desires of students and their families have changed over the past ten years, more so than in any other period I have seen" said Connie Carson, president of the Association of College and University Housing OfficersInternational. (Dessoff) Carson continues to say "There is a lot more interest in housing with more amenities than the basic ones that historically have been provided on campuses. Suite style and apartment housing has become the trend." (Dessoff) What were once considered to be luxuries in student housing - kitchens, private bedrooms, private bathrooms, social spaces and lounges - are now expected. (School Facilities) Internet connectivity - including wireless connections and cable are considered requirements. Cognizant of the world in which they live, students also demand a safe and secure environment.

Expectations of students also include increased connectivity for the "toys" that are now an essential part of their lifestyle - cell phones and IPods, games, MP3 devices, computers, printers and other essentials for the modern teenager. Laundry facilities, HVAC that can be controlled in each room, fitness facilities and common spaces to socialize and/or study are expected amenities. Essentially, the new student wants "...things in their own spaces. And they are used to leading busy academic, extracurricular, cyber, and social lives." (Miller)

\section{HOUSING PREFERENCES OF THE LONGWOOD STUDENT}

In an effort to determine the housing preferences of the Longwood student, 325 undergraduate students were surveyed. The results indicate that students overwhelmingly reject the traditional dormitory as a housing option indicating their expectations of privacy and state-of-the-art amenities.

Longwood University is a state supported school that requires students to live in campus housing until their third year. Of the 325 students surveyed in the April 2010 Student Housing Preference Survey, 10.5\% were freshmen, $22.8 \%$ were sophomores, $29.5 \%$ were juniors, and $37.2 \%$ were seniors. Sixty-three percent of the respondents were female and $37 \%$ were male. This does not represent the gender distribution of the university population and may be a function of the classes that were surveyed. However, when the results were analyzed using gender as a discriminant, the results were remarkably similar. Thus, it appears that gender is not a factor in housing preferences. The break-down by type of housing currently occupied is shown on Figure 1 below.

Figure 1. Percent of Survey Respondents in Current Housing

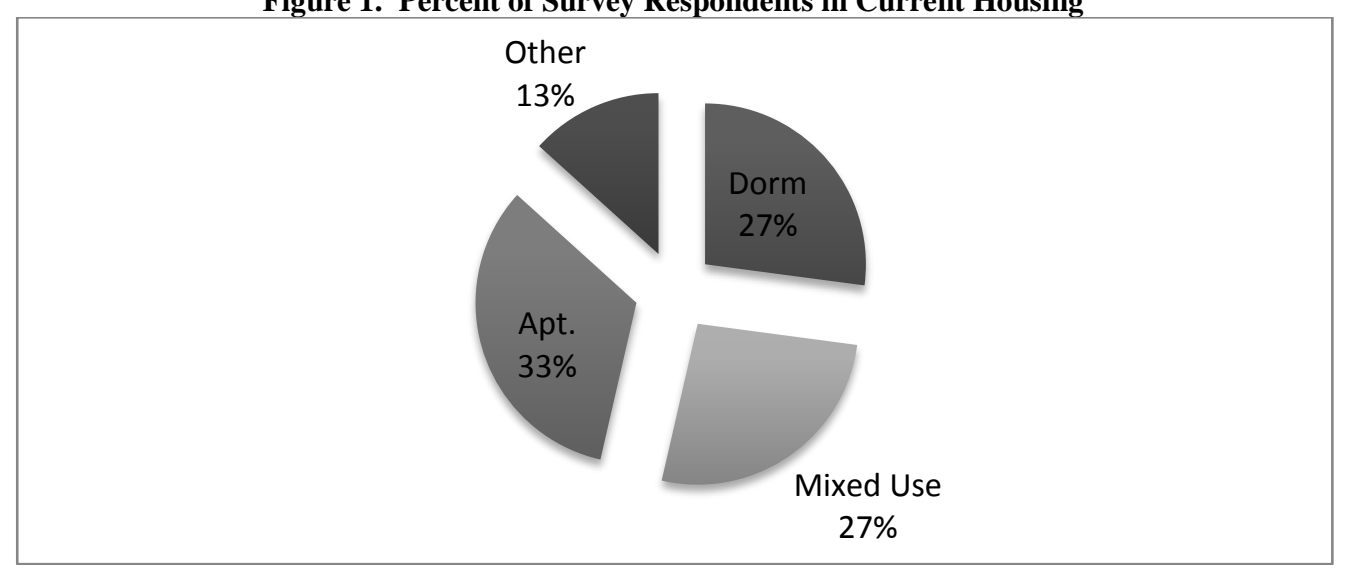

Of the survey respondents, $27.1 \%$ indicated that they share a bedroom and live in a traditional dormitory and share a bathroom and when asked about next year, only $17.3 \%$ said that they were going to live in a traditional 
dormitory. When asked about their preferred form of housing, only $3.2 \%$ said that they preferred traditional dormitory living. The first choice for university-owned student housing was mixed-use apartment-style housing with shops and restaurants on the ground floor located within walking distance of the university. The housing preferences of those surveyed is illustrated by Figure 2 below.

Figure 2. First Choice Housing Preferences

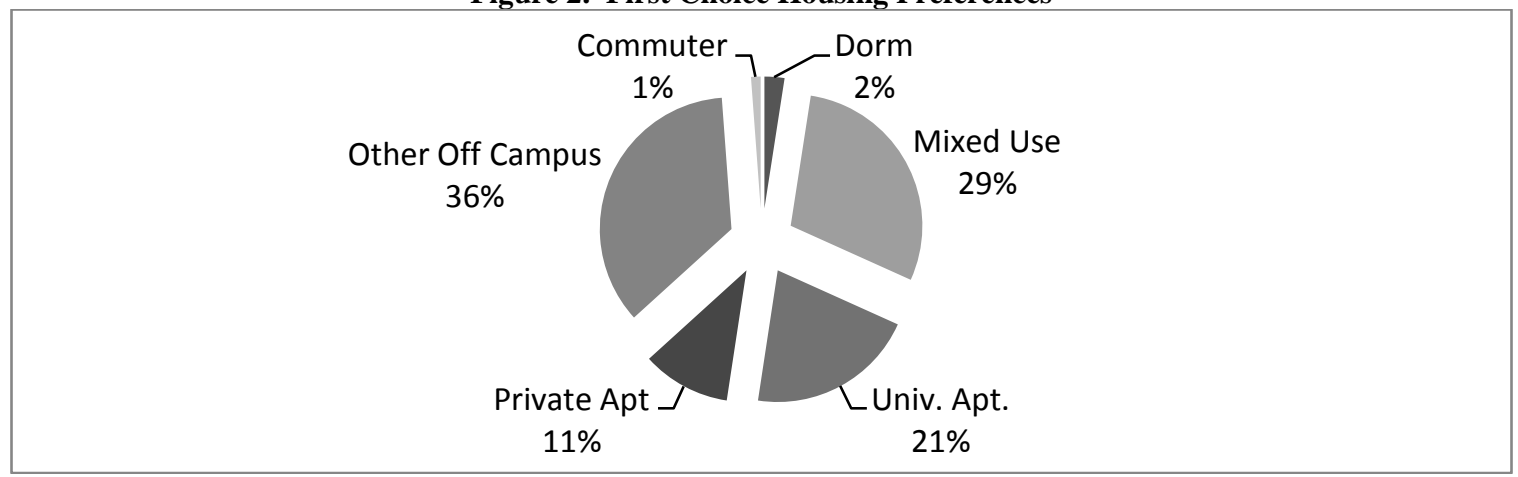

It is interesting to note that $11.1 \%$ of the respondents preferred to live in a privately owned and operated apartment complex that is designed for students and featured private bedrooms and baths and $36.3 \%$ of the respondents preferred other off-campus housing. Thus, including the commuter students, almost half (48.6\%) of the students would rather live off-campus. This preference is important to note for several reasons. As colleges and universities utilize real estate foundation boards to build student housing, there are fewer restrictions if the housing is not built on state property. Given the current economic climate and the desire to provide affordable education options, there is a trend at the state level to prohibit state schools from requiring students to live on-campus, a move that would require universities to compete on the basis of both cost and amenities.

The Student Housing Survey revealed the important role that cost plays in the housing decision. Figure 3 below illustrates that for one in four $(24.8 \%)$ of those surveyed, cost either had a large impact or was a deciding factor and for an additional one-third $(33.9 \%)$ of the respondents, cost was somewhat of a factor.

Figure 3. Role of Cost in Choosing Housing

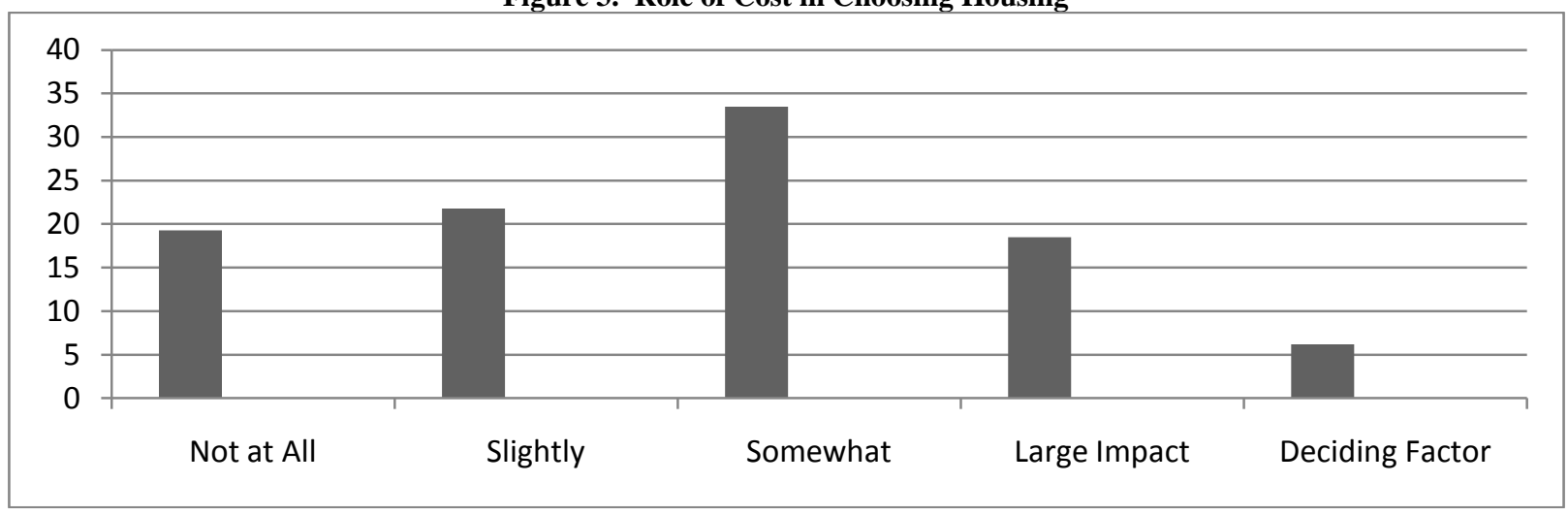

Of those surveyed, almost half (47\%) believed that it is more expensive to live on campus than it is to live off-campus. Approximately half $(50.8 \%)$ of the survey respondents said that they make their own housing decisions; $28 \%$ of the housing decisions are made in equal consultation with a student's parents, $9.2 \%$ of the decisions are made exclusively by the parents and in $10.5 \%$ of the cases, the housing decision is made by a third 
party. With $78.8 \%$ of the students having a significant role in choosing student housing, what amenities do millennial students prefer? An overwhelming majority (87.5\%) of students would rather have a double bed. In addition, a majority of students are willing to pay an additional fee to have a private room, a private bath, access to a kitchen and on-site parking.

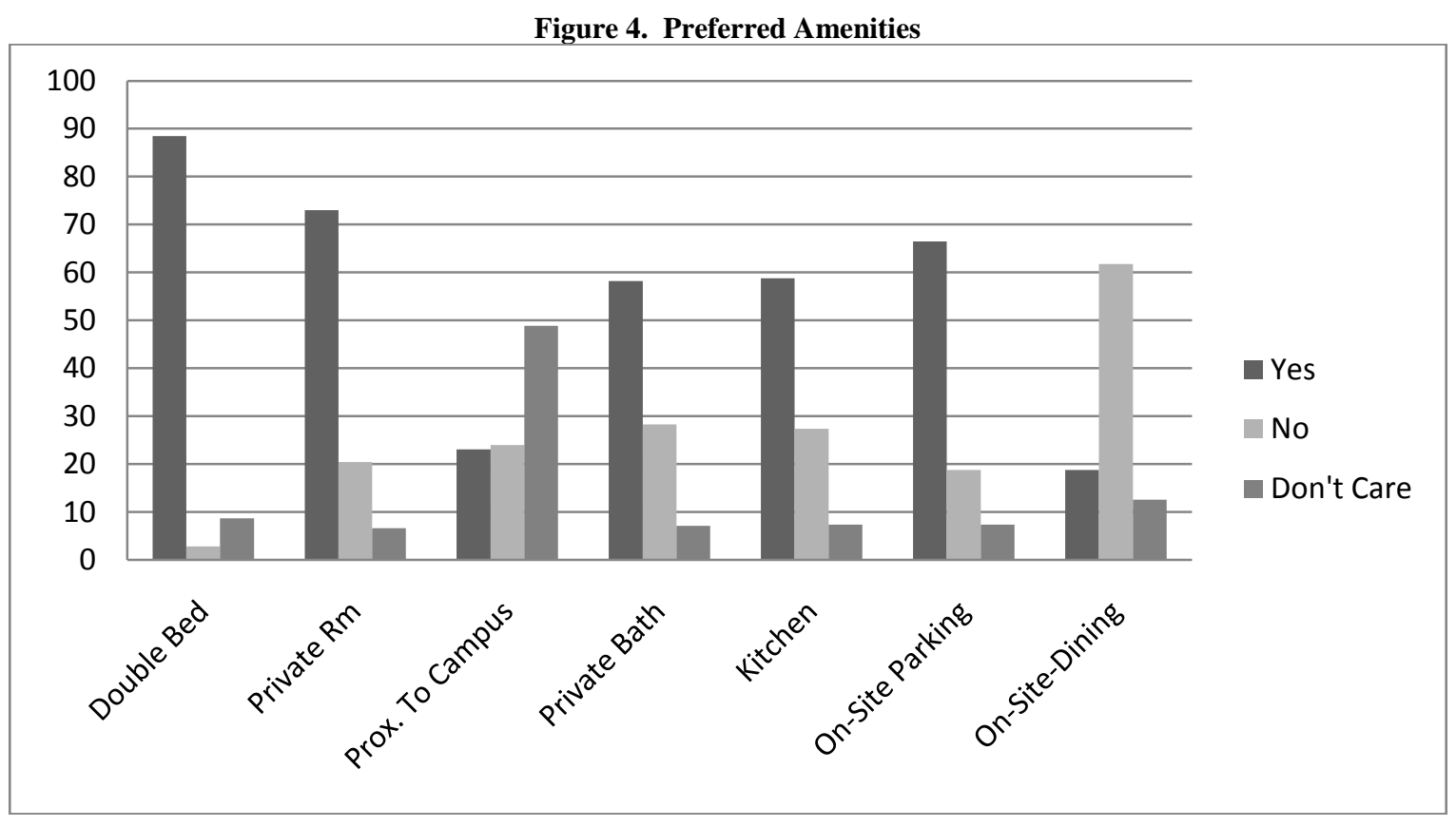

When asked to rank the most important consideration in choosing housing, "security" was ranked first, followed by proximity to campus and cost. For a majority of respondents, a "deal breaker" in the housing decision included: no Internet access $(92.9 \%)$, no laundry facilities on premises (84.9\%), no cable TV (75.7\%) and no kitchen (57.4\%). For approximately half of the respondents, sharing a bedroom was a "deal breaker" $(49.3 \%)$ as were twin beds $(42.1 \%)$. Surprisingly, sharing a bathroom was only a deal breaker for $11.7 \%$

\section{OTHER TRENDS IN STUDENT HOUSING}

Another trend identified by University Business is the concept of Live and Learn spaces where students' inand-out of classroom academic experiences is integrated. (Angelo) Universities across the US are attempting to foster a collegial environment by blurring the lines between academic and non-academic pursuits. In particular, many universities are offering themed housing such as a "Spanish House" where residents live and may eat while practicing their conversational Spanish. Additionally, many universities are fostering a collegial environment by creating "residential colleges" that house both students and faculty. Although there is not a standard model, in many residential colleges, some classes may be taught onsite and some of the meals are taken together.

\section{FINANCING HOUSING}

Today's students expect to have the amenities of home while away at school. Living in a traditional campus residence hall, laid out in suites with shared bathrooms and two students per room is rapidly becoming a thing of the past. Offering an apartment style option, typically for upperclassmen, is becoming more and more prevalent. "Off campus housing trends have become more upscale, as students now look for amenities typically associated with apartment living that rarely exist in dorm environments." (Marcus \& Millichap) In order to stay competitive, colleges and universities are now faced with the issue of diversifying their housing options. 
A more immediate problem facing institutions is the expected increase in college enrollments and the ability of schools to meet that demand. Enrollments are on an upward trajectory and are expected to remain so for the next four years. Total enrollment is expected to increase 8\% from 2009 to 2012. (IPM Amicus) "Due to high construction costs, most universities have been unable to keep up with mounting housing demand. Developers have responded with the delivery of more than 57,000 beds since 2000 , while an additional 23,000 beds are forecast to come online by the end of 2009." (Marcus \& Millichap) Virginia has two of the ten fastest growing universities in the country: George Mason and Virginia Commonwealth. Consequently, the topic of providing beds is one of immediate concern in this state. (Marcus \& Millichap)

In Virginia, public educational institutions have used the traditional 9C and 9D bond programs and financed student housing construction and/or renovation through the Commonwealth Bond Issuance program. This program is generally reserved for building 50 to 100 year structures and the typical apartment-style student housing will not meet the criteria for the state's bond financing programs.

As a result of the dilemma created by student demand for apartment-style housing, many state-supported colleges and universities have created a separate legal entity, a real estate foundation, to assist in the construction and financing of student housing projects. University affiliated foundations have greater flexibility in the construction that may be used, particularly when building in close proximity, but not actually on, Commonwealth property. As a rule, building a 30-year structure under the supervision of a local building official is less expensive than a traditional state building - and considerably less time consuming. Additionally, trends over the past 10 to 15 years suggest that building residential space with longer than a 30-year life isn't prudent due to the rapid technical innovations, cultural changes and expectations of students.

With a support pledge from the college or university, the affiliated real estate foundation can pursue financing through tax exempt revenue bonds, using a local government Industrial Development Authority (IDA). For instance, in Virginia, the state small business financing authority may act as the issuer and a bank as a remarketing agent. Credit enhancement for these bonds typically comes either in the form of a bank- issued letter of credit or bond insurance. Although most small schools do not typically pursue this option, a college or university may have its own individual bond rating that enables either the school or its affiliated foundation the opportunity of doing a bond issue without the benefit of credit enhancement. With the recent volatility in domestic and international financial markets, bond insurance is becoming more and more a thing of the past. Currently, there are only two viable options remaining in the marketplace for providing bond insurance and if conditions worsen over the next 24 to 36 months, these companies may be forced to totally abandon the bond insurance business.

As access to credit enhancement becomes more challenging, construction contractors have begun to look at the traditional design/build or design/bid/build structures through a new lens. Many larger contractors have developed strategic alliances with large investment banking operations thus enabling them to solicit construction business by offering a turnkey solution - i.e. the contractor delivers a completed project to the customer that could either be financed in a traditional principal and interest mortgage note or ground leased by the contractor, developed and master leased back to the college or university. At the end of the master lease term, the property would revert back to the university. This approach allows the developer to depreciate the structure(s) and take advantage of any tax credit opportunities that may exist in the marketplace. Neither a state supported school nor its affiliated foundation would receive any benefit from depreciation or tax credits. A "for-profit" construction firm on the other hand, could theoretically derive significant tax benefits - thereby enabling them to put a financially attractive lease option in the hands of the lessee. This type of non-traditional financing will likely become much more commonplace as the country digs its way out of the current economic situation.

\section{CONCLUSION}

Millennial students have significantly higher expectations for student housing than their parents did and are willing to pay an additional fee for certain amenities. As colleges and universities plan to take older dorms off-line and build additional housing, it is important to examine housing options preferred by students. Given the current economic situation, universities may find it expedient to join forces with their prior competitors, private developers, and share in the lucrative revenue stream provided by student housing. Given the trend of providing social 
amenities to students, the authors were surprised to find that students are somewhat ambivalent about residential colleges and themed housing with a minority of students open to the idea of living in one of these unique communities.

While security and cost are important considerations, the Student Housing Survey revealed the following "Top Ten" amenities that are either "very important" or "somewhat important" to students:

1. Private bedroom $(95.5 \%)$

2. Onsite parking (92\%)

3. Double beds $(91.3 \%)$

4. Onsite laundry facilities $(90.3 \%)$

5. Internet access $(88.8 \%)$

6. Proximity to campus (73.3\%)

7. Fitness Center $(73.3 \%)$

8. Private bathroom $(73 \%)$

9. Cable TV $(56.4 \%)$

10. Satellite Dining (50\%)

The expectations of amenities that should be included in student housing are increasing at a time when state funding is decreasing. Restrictions on the types of housing that a bond issue may be used to build may prohibit an institution from building apartment-style housing that is overwhelmingly preferred by today's students. It is recommended that state supported colleges and universities form a separate entity, a real estate foundation, to be free of many of the state's building restrictions and to avail themselves of alternative forms of financing.

\section{REFERENCES}

1. Angelo, Jean Marie and Nicole Rivard. "If you build it they will come: 6 trends to build by, from campus innovators in higher ed housing - Special Report: Campus Housing". University Business http://findarticles.com/p/articles/mi_mOLSH/is_5_6/ai_102090783/pg_5/?tag=content;coll. Accessed $\underline{3 / 15 / 2010 .}$

2. Cain, David and Gary Reynolds. "The Impact of Facilities on Recruitment and Retention of Students. Part I." Facilities Manager Magazine. Vol. 22, March -April, 2006.

3. Desoff, Alan. "Campus Auxiliary Facilities; Universities Stress to Accommodate Student Desires and Future Trends." May-June 2007. Pp 20-23.

4. "Economic Challenges Lead to Lower Non-tuition Revenues and Higher Prices at Colleges and Universities." College Board 2010. Http://www.collegeboard.com/press/releases/208962.html

5. Hill, Christopher. "Housing Trends of the $21^{\text {st }}$ Century: Addressing Today's Student Expectations." AIA Convention Address, Boston, May 15, 2008.

6. Marcus and Millichap. Special Report: Student Housing Making the Grade with Investors. 2009. www.MarcusMillichap.com. Accessed 5/15/2010.

7. Miller, Herman. "Room and Board Redefined" HermanMiller.com. accessed 3/24/2010.

8. "New Trends in Student Housing." Http://schoolfacilities.com/_coreModules/content/contentDisplau_print.aspx?content...5/16/2010.

9. $\quad$ "The Expert: Student Housing Outlook Remains Healthy.” IPM Amicus. Institutional Project Management. http://www.ipm-amicus.com/about/press/expert-student-housing-outlook-remains-healthy. accessed $3 / 15 / 2010 /$ 